\title{
UGANDA POD RZĄDAMI YOWERIEGO MUSEVENIEGO. OD „MODELOWEJ" ODBUDOWY POKONFLIKTOWEJ DO INKLUZYWNEJ SIECI PATRONAŻU*
}

\author{
Andrzej Polus**
}

\author{
UGANDA UNDER YOWERI MUSEVENI. \\ FROM THE RAW MODEL OF POSTCONFLICT RECONSTRUCTION TO \\ THE INCLUSIVE PATRONAGE NETWORK
}

\begin{abstract}
The principal aim of this paper is to critically examine evolution of the Ugandan political regime during the Yoweri Museveni rule and the very nature and socio-political consequences of the vast, inclusive patronage network existence. This paper is based primarily on field research conducted in Uganda in June and July 2014.

The paper is divided into three parts. The first part briefly presents evolution of the Ugandan political regime. In the second part the very issue of the nature of the political patronage in Uganda was raised. The last section concludes.
\end{abstract}

\section{KEYWORDS}

Uganda, patronage, Yoweri Museveni, postconflict reconstruction

* Artykuł jest wynikiem badań terenowych w Ugandzie sfinansowanych przez Narodowe Centrum Nauki w ramach projektu nr UMO-2012/07/B/HS5/03851, pt. Perspektywy rozwoju nowych państw naftowych $w$ Afryce na przykładzie Ugandy.

** Uniwersytet Wrocławski, Instytut Studiów Międzynarodowych. 


\section{WPROWADZENIE}

Uganda jest państwem wieloetnicznym, w którym żadna z dotychczasowych zmian na stanowisku głowy państwa, od momentu uzyskania niepodległości od Wielkiej Brytanii w 1962 roku, nie odbyła się w sposób pokojowy ${ }^{1}$. W latach 90. ubiegłego wieku Uganda prezentowana była jako przykład subsaharyjskiego państwa, które poza postępującą odbudową pokonfliktową z sukcesami wprowadza reformy gospodarcze i polityczne ${ }^{2}$. Prezydent Yoweri Museveni (w Ugandzie określany akronimem M7) zaliczany był do nowej generacji (ang. new block) afrykańskich polityków ${ }^{3}$, którzy mieli wprowadzić nową jakość do polityki w tym regionie świata. W uznaniu osiągnięć transformacji politycznej i gospodarczej Uganda została włączona do Programu Redukcji Zobowiązań Najbiedniejszych i Najbardziej Zadłużonych Państw Świata. Kampala uzyskała również dostęp do pomocy międzynarodowej, która stanowiła znaczną część budżetu państwa ${ }^{4}$. Międzynarodowe uznanie uzyskały także reforma decentralizacyjna oraz implementacja programu walki $z$ epidemią HIV/AIDS. Uganda jest też najważniejszym sojusznikiem Stanów Zjednoczonych w regionie Wielkich Jezior. Ugandyjskie siły zbrojne (UPDF) są aktywnie zaangażowane w operacje militarne w Somalii i Sudanie Południowym, zaś liczne kontrowersje wiążą się z kontrolowaniem handlu surowcami mineralnymi wydobywanymi na wschodzie Demokratycznej Republice Konga przez ugandyjską armię. W ostatnich latach coraz częściej pojawiają się artykuły naukowe i teksty publicystyczne oskarżające prezydenta Museveniego o autorytarne zapędy i niemożliwość prowadzenia działalności opozycyjnej w tym państwie ${ }^{5}$. Ugandyjski reżim polityczny określany jest obecnie mianami: „semiautorytaryzmu”, Pax Musevenica ${ }^{7}$ czy „reżimu hybrydowego”, łączącego w sobie cyklicznie odbywające się wybory przy jednoczesnej niemoż-

1 Uganda Pocket Facts. A Companion Guide to the Country, Its History, Culture, Economy and Politics, ed. A. Gakwandi, Kampala 1999, s. 37-42.

2 Por. B. Jones, Beyond the State in Rural Uganda, Edinburgh 2009, s. 1-2; A. Thomson, An Introduction to African Politics, London and New York 2006, s. 147.

3 P.J. Schraeder, African International Relations, [w:] Understanding Contemporary Africa, ed. A.A. Gordon, D.L. Gordon, Boulder-London 2001, s. 178.

4 J. Kigongo E. Mubazi, Is Uganda An Economic Star Performer?, „Mawazo” 2011, vol. 10, no. 3, s. $146-147$.

5 O. Kobusingye, The Correct Line? Uganda Under Museveni, London 2010.

${ }^{6}$ A.M. Tripp, The Changing Face of Authoritarianism in Africa: The Case of Uganda, „Africa Today” 2004 , vol. 50 , issue 3 , s. 4 .

7 J.B. Rubougoya, Regime Hegemony in Museveni's Uganda. Pax Musevenica, New York 2007. 
liwości odsunięcia partii rządzącej od władzy. Piętnowana jest endogeniczna w Ugandzie korupcja. Nagłówki gazet w 2014 roku zdominowała fala krytyki pod adresem ugandyjskich władz po podpisaniu przez prezydenta Museveniego ustaw penalizujących homoseksualizm. Wiele z państw europejskich zawiesiło wówczas programy pomocowe dla Ugandy. Owa zmiana narracji poświęconych Ugandzie w zachodnich środkach masowego przekazu i rola tego państwa w regionie Wielkich Jezior były głównymi przyczynami podjęcia tematu genezy i procesu zmian, jakie zaszły na arenie politycznej tego kraju pod trzydziestoletnimi rządami Yoweriego Museveniego.

Celem artykułu jest omówienie ewolucji ugandyjskiego reżimu politycznego oraz natury i konsekwencji istnienia kluczowej dla stabilności politycznej tego państwa inkluzywnej sieci patronażu. Dodatkowo, ze względu na niezmiernie znikomą literaturę poświęconą sytuacji politycznej Ugandy na gruncie polskim, tekst ma również na celu wzbogacenie krajowego dyskursu na temat stabilności politycznej państw położonych w Afryce Subsaharyjskiej.

W trakcie prac nad tekstem autor kierował się społeczno-konstruktywistyczną epistemologią, dążąc raczej do zrozumienia natury ugandyjskiej polityki, a nie znalezienia jej kompleksowego wyjaśnienia. Wśród głównych technik badawczych należy wymienić: kontekstualizację, analizę piśmiennictwa, krytyczną analizę ugandyjskiego dyskursu politycznego, obserwację oraz częściowo ustrukturyzowane wywiady pogłębione. Wywiady pogłębione przeprowadzone zostały w Kampali w lipcu i sierpniu $2014 \mathrm{roku}^{8} \mathrm{z}$ ugandyjskimi politykami, przedstawicielami działających w tym państwie organizacji pozarządowych, pracownikami akademickimi Uniwersytetów Makerere i Victoria, prawnikami, dziennikarzami oraz osobami prowadzącymi w Ugandzie działalność gospodarczą. Nie bez znaczenia dla wyrobienia ogólnego poglądu na sytuację polityczną w Ugandzie były dziesiątki rozmów przeprowadzonych przez autora z przypadkowo spotkanymi Ugandyjczykami.

Artykuł został podzielony na trzy części. W części pierwszej została zarysowana ewolucja ugandyjskiego reżimu politycznego po przejęciu władzy przez Yoweriego Museveniego. W kolejnej części tekstu zostały omówione natura i uwarunkowania funkcjonowania sieci patronażu w Ugandzie. Ostatnia część

8 Autor pragnie podziękować Wojciechowi Tycholizowi, z którym prowadził badania terenowe w Ugandzie w czerwcu i lipcu 2014 roku. Bez profesjonalizmu, dociekliwości oraz determinacji $\mathrm{w}$ dążeniu do wywiązania się z badań badawczych Wojciecha Tycholiza nie zostałby zebrany materiał faktograficzny, który stanowił podstawę niniejszego artykułu. 
artykułu, pełniąca zarazem funkcję konkluzji, jest refleksją nad konsekwencjami oparcia reżimu politycznego Ugandy na inkluzyjnej sieci patronażu.

\section{EWOLUCJA UGANDYJSKIEGO REŻIMU POLITYCZNEGO}

W momencie przejęcia władzy w Ugandzie przez Yoweriego Museveniego, Narodowy Ruch Oporu (ang. National Resistance Movemnt, NRM) tworzyli partyzanci, których głównym dążeniem było ustabilizowanie sytuację w kraju. Co więcej, żołnierze NRM mili pełną świadomość, że muszą podzielić się władzą z cywilami i innymi grupami politycznymi aktywnymi wówczas w Ugandzie, gdyż samodzielne rządzenie niemalże na pewno stałoby się przyczyną wznowienia walk. Wielu ugandyjskich intelektualistów, z którymi przeprowadzone były wywiady, podkreślało, iż w drugiej połowie lat 80 . Yoweri Museveni zachowywał się „patriotycznie”, zaś wojska NRM po zajęciu Kampali, w odróżnieniu od innych partyzantek, nie dopuszczały się grabieży i gwałtów; ich zachowania określano jako „purytańskie”. Co więcej, stanowiska państwowe w tym okresie przydzielane były nie na zasadzie przynależności do określonej grupy etnicznej, a raczej według kwalifikacji kandydatów (Museveni od zawsze dbał, aby jedna grupa etniczna nie zdominowała administracji państwowej). Niewątpliwie 15 lat prowadzenia walki zbrojnej wywarło wpływ na Yoweriego Museveniego i nie zamierzał on przejąć władzy dla samego jej przejęcia. Wydaje się również, że po doświadczeniu terroru rządów Idi Amina i Miltona Obote inny styl sprawowania władzy zaprezentowany przez Museveniego oraz ogromne oczekiwania społeczne co do zapewnienia stabilizacji w państwie stały się podstawą autentycznego poparcia Ugandyjczyków dla wprowadzanych przez niego zmian. Pragnący pozostać anonimowym bliski przyjaciel syna prezydenta, opisując Yoweriego Museveniego, stwierdził, że od zawsze chciał on być pamiętany jako reformator, „jako polityk który przekształcił Ugandę w państwo rozwinięte”. Museveni nie chciał również wprowadzać represji jako głównego instrumentu prowadzenia polityki w Ugandzie, mając świadomość, że przemoc może w łatwy sposób przyczynić się do powstania zbrojnej opozycji wobec $\mathrm{NRM}^{10}$. Czynniki osobowościowe są bardzo często pomijane przez politologów, jednakże w sytuacji

\footnotetext{
9 Wywiad z prof. Julius Kiiza, Makerere University, Kampala, 23.06.2014.

$10 \mathrm{Na}$ przełomie lat 80 . i 90 . relatywnie łatwo można było tworzyć grupy zbrojne w tym regionie Afryki, co ułatwiała niestabilna sytuacja w Sudanie i Zairze/Demokratycznej Republice Konga.
} 
gdy Yoweri Museveni jest postacią centralną w ugandyjskiej polityce, muszą być one brane pod uwagę.

Po przejęciu władzy w 1986 roku, Yoweri Museveni zakazał działalności politycznej i wprowadził system określany mianem bezpartyjnego „ruchu” (ang. movement system), który tworzyli liderzy lokalnych społeczności, politycy, aktywiści, jednakże bez zaznaczania przynależności partyjnej ${ }^{11}$. Niemniej trzon „ruchu” stanowili bojownicy NRM. Szeroki ogólnokrajowy „ruch” miał w założeniu uchronić państwo przed kolejnymi wybuchami przemocy związanymi z walką o władzę $e^{12}$. Główną tezą artykułu jest twierdzenie, że obecna sytuacja w Ugandzie jest niezamierzoną wypadkową dostosowywania się elity rządzącej do zmieniających się uwarunkowań, przy jednoczesnym zaznaczeniu, że uwarunkowania te były w głównej mierze kreowane właśnie przez NRM i prezydenta Museveniego. Innymi słowy - sieć patronażu jest niezamierzonym efektem trzydziestoletniej polityki utrzymywania się M7 u władzy.

Głównymi czynnikami zewnętrznymi, z którymi musiała się liczyć ugandyjska elita polityczna w drugiej połowie lat 80 . ubiegłego wieku, były: załamanie gospodarcze, destabilizacja Sudanu Południowego i Demokratycznej Republiki Konga oraz rebelie wybuchające na północy Ugandy. Bezpośrednio po przejęciu władzy NRM planował prowadzić niezależną politykę gospodarczą, w której państwo odgrywałoby rolę centralną, jednakże pogarszająca się sytuacja ekonomiczna Ugandy (inflacja sięgająca 300\% w ujęciu rocznym) zmusiła Museveniego do zwrócenia się o pomoc do Międzynarodowych Instytucji Finansowych i zaakceptowania warunków Strukturalnych Programów Dostosowawczych (SAP) ${ }^{13}$. W literaturze przedmiotu funkcjonuje interesująca debata na temat skutków SAP dla utrzymywania systemów neopatrymonialnych w Afryce Subsaharyjskiej. Z teoretycznego punktu widzenia wymuszanie przez donatorów redukcji zatrudnienia $\mathrm{w}$ administracji państwowej, zakazy subsydiowania produkcji

11 Por. W. Muhumuza, The Performance of Decentralisation and Public Sector Accountability Reforms in Uganda, [w:] Thirty Years of Public Sector Reforms in Africa. Selected Country Experiences, ed. P. Chanie, P.B. Mihyo, Kampala 2013, s. 268; A.M. Tripp, Museveni's Uganda. Paradoxes of Power in a Hybrid Regime, Boulder-London 2010, s. 2. Idea „bezpartyjnego ruchu”, który powinien przejąć władzę w Ugandzie celem uniknięcia dalszych podziałów w społeczeństwie, narodziła się w 1982 roku podczas działań partyzanckich (tzw. bush war) prowadzonych przez NRM, Y.K. Museveni, What is Africa's Problem?, Minneapolis 2000, s. XXVII.

12 Ugandyjski Parlament podjął uchwałę o zakazie działalności partii politycznych dopiero w 1992 roku.

13 E. Green, Patronage, District Creation, and Reform in Uganda, „Studies in Comparative International Development" 2010, vol. 45 issue 1, s. 85. 
czy prywatyzacja państwowych przedsiębiorstw powinny się przyczyniać do zmniejszania zasobów, którymi dysponuje lider państwa i poprzez które może utrzymywać sieć swoich klientów. Jednakże, jak w przekonujący sposób argumentują Andrew Mwenda i Roger Tangri, w przypadku Ugandy wsparcie reform przez zagranicznych donatorów przyczyniło się do dostępu liderów państwa do dodatkowych środków (od 500 do 800 mln USD rocznie w latach 90. ubiegłego wieku), które były użyte dla tworzenia sieci patronażu ${ }^{14}$. Niemniej rząd, chcąc mieć zagwarantowany dostęp do środków pochodzących z zagranicy, musiał wprowadzać w życie reformy gospodarcze i polityczne, które w krótkookresowej perspektywie czasowej mogły prowadzić do spadku jego popularności i odsunięcia od władzy. Reformy były zatem wprowadzane w taki sposób, aby osoby uzyskujące dzięki nim dostęp do publicznych pieniędzy gwarantowały utrzymanie się u władzy NRM, co racjonalizowane było koniecznością niedopuszczenia do kolejnego konfliktu wewnętrznego. Ponieważ w latach 90. pluralizm polityczny był w Ugandzie zakazany, jedyną drogą kariery stawało się włączenie do bezpartyjnego „ruchu”, zaś kierujący nim, mając świadomość, że dalsze reformy są nieuniknione, zaczęli przydzielać stanowiska na bazie lojalności wobec nadających je patronów, a nie kompetencji do pełnienia określonych funkcji. To z kolei zaowocowało widocznym obecnie i omówionym w kolejnej części tekstu przerostem biurokracji i wpisaną w naturę sieci patronażu niemożliwością efektywnego wypełniania zadań przez urzędników państwowych.

Za symboliczny początek sieci patronażu w polityce ugandyjskiej uznany może być rok 1995 (choć oczywiście przyznawanie stanowisk za lojalność miało miejsce wcześniej), w którym przyjęto nową ustawę zasadniczą ustanawiającą system prezydencki ${ }^{15}$. W drugiej połowie lat 90. prezydent Museveni wielokrotnie musiał odpierać oskarżenia o zdradzenie ideałów NRM i ugruntowywanie jednopartyjnego reżimu politycznego pod pozorem niedopuszczania do konfrontacji politycznej, która mogłaby przerodzić się w otwarty konflikt. Głównymi krytykami Museveniego zostali jego dawni towarzysze broni - pułkownik Kizza Besigye (który starł się z M7 w wyborach prezydenckich 2001 roku, a następnie stanął na czele opozycyjnego wobec NRM - Forum dla Demokratycznej Zmiany) oraz generał Eriya Kategaya. Na przełomie XX wieku coraz większe kontrowersje

14 A. Mwenda, R. Tangri, Patronage Politics, Donor Reforms, and Regime Consolidation in Uganda, „African Affairs” 2005, vol. 104, issue 416, s. 451.

15 A.M. Tripp, The Changing..., op.cit., s. 8. 
zaczęła budzić otwarcie sugerowana przez M7 konieczność zmiany konstytucji, tak by mógł startować po raz trzeci w wyborach prezydenckich.

W 2005 roku w Ugandzie została znowelizowana ustawa zasadnicza. Dwie najważniejsze zmiany zostały wprowadzone na zasadzie targu pomiędzy Musevenim a jego przeciwnikami w NRM. Po pierwsze, zniesiony został limit dwóch kadencji prezydenckich, co w praktyce pozwoliło M7 startować z sukcesem w kolejnych wyborach. Ceną za to ustępstwo było zniesienie zakazu prowadzenie działalności politycznej poza NRM, co otworzyło drogę do rozłamów w Narodowym Ruchu Oporu i pojawienia się oficjalnej opozycji. Powstanie licznych ugrupowań opozycyjnych skomplikowało sytuację polityczną w Ugandzie, zaś obóz rządzący, chcąc utrzymać się u władzy, w dalszym ciągu rozbudowywał sieć patronażu.

\section{NATURA I UWARUNKOWANIA FUNKCJONOWANIA SIECI PATRONAŻU}

Yoweri Museveni jest centralną postacią ugandyjskiego reżimu politycznego. Podstawą jego sukcesu jest utrzymanie kontroli nad armią ${ }^{16}$. Kontrola ta jest utrzymywana przede wszystkim poprzez odpowiednią obsadę stanowisk głównodowodzących UPDF oraz poprzez czerpanie przez armię korzyści dzięki rządowym kontraktom. Zdecydowana większość respondentów podkreślała w swoich wypowiedziach bezpośrednią lub pośrednią obecność sił zbrojnych w wielu sektorach gospodarki Ugandy. Nie mniej ważny jest perfomatywny wymiar oficjalnych wystąpień M7. Inaczej niż inni liderzy z wojskową przeszłością (np. prezydent Botswany Ian Khama) nie unika on tytułowania go stopniem generała $^{17}$. Ugandyjskie miasta oplakatowane są wizerunkami prezydenta w mundurze. Museveni szczyci się swoją wojskową przeszłością i funkcją głównodowodzącego sił zbrojnych. W tym kontekście niezwykle istotna jest społeczna percepcja UPDF. O ile Ugandyjczycy w zasadzie w ogóle nie czują respektu przed policją - z policją można na przykład negocjować łapówki - to pojawienie się na ulicy wojska w czasie demonstracji sprawia, że ludzie momentalnie przestają

16 Africa Confidential, Museveni’s Military, „Africa Confidential”, 4 November 2005, vol. 46, no. 22, s. 2.

17 Prezydent oficjalnie odszedł $\mathrm{z}$ armii, „by walczyć na innych frontach” (ang. fight new battles), pozostaje on jednak jako głowa państwa głównodowodzącym UPDF. 
skandować hasła. Społeczeństwo wydaje się wiedzieć, że prezydent ma pod swoją kontrolą środki przymusu i mógłby bez większych problemów wprowadzić w Ugandzie terror podobny do tego, którego państwo to doświadczyło pod rządami Idi Amina i Miltona Obote. Na zadawane wielokrotnie pytanie - dlaczego M7 pozostaje u władzy, jeśli informacje o skandalach korupcyjnych, niegospodarności i nepotyzmie są powszechnie znane, znakomita większość respondentów odpowiadała - „Museveni jest gwarantem pokoju w Ugandzie” ${ }^{18}$. Pomimo że większość respondentów nie pamiętała lat 70. i 80. ubiegłego wieku (liczbę ofiar reżimów Amina i Obote szacuje się na ponad pół miliona), niezwykle silna jest zbiorowa pamięć państwowego terroru. Tym samym kwestionowanie dominującej pozycji NRM mogłoby się wiązać z kolejnym konfliktem wewnętrznym, który w opinii większości respondentów i tak wygrałby Museveni ze względu na lojalność armii wobec prezydenta. Takie postrzeganie elity rządzącej przez Ugandyjczyków wiąże się bezpośrednio z podkreślaną przez opozycję rosnącą pasywnością ugandyjskiego społeczeństwa i brakiem zaangażowania w życie polityczne państwa. Zdecydowana większość Ugandyjczyków jest zajęta poszukiwaniem zajęć zarobkowych, które pozwoliłyby im wykarmić i wyedukować rodziny, co dodatkowo sprawia, że polityka jawi się jako sfera niedostępna dla przeciętnego obywatela. Innymi słowy, jednym z największych zwycięstw M7 jest wpojenie ugandyjskiemu społeczeństwu przekonania, że będzie on dożywotnio pełnił urząd głowy państwa. Wydaje się, że bez pasywnej postawy społeczeństwa, sieć patronażu, która spaja Ugandę, byłaby niemożliwa do utrzymania.

Trzecim obok kontroli nad armią i pasywnością ugandyjskiego społeczeństwa elementem, który pozwala funkcjonować patronażowi w Ugandzie, jest zasięg sieci patronażu. Przenika ona wszystkie sfery ugandyjskiego życia społecznego, kulturowego, gospodarczego, politycznego, a nawet religijnego ${ }^{19}$. Próba jej „rozmontowania” naruszyłaby bardzo wiele interesów, jednakże ugandyjski patrymonializm jest inkluzywny ze swojej natury. O ile na początku XXI wieku w Ugandzie dochodziło do represji za działalność opozycyjną, to obecnie osoby nieprzychylne wobec rządu są bardzo często obsadzane na lukratywnych stanowiskach państwowych ${ }^{20}$. Sytuacje te są tak częste, że wielu respondentów zwracało uwagę, że głośna krytyka polityki NRM jest najprostszą odskocznią do

18 Wywiad z Rose Nassanga, Chief Administrative Officer, siedziba Forum for Democratic Change, Kampala 24.06.2014.

19 Wywiad z prof. Julius Kiiza, op.cit.

20 Wywiad z dr Lawrence Bategeka, EPRC, Makerere University, Kampala, 24.06.2014. 
kariery, gdyż wówczas istnieje bardzo duże prawdopodobieństwo, że zostanie się inkorporowanym do sieci patronażu.

Czwartym elementem, który pozwala na funkcjonowanie inkulzywnej sieci patronażu w Ugandzie, jest wytworzony w ostatniej dekadzie system „wentyli bezpieczeństwa” ${ }^{21}$. Przez „wentyl bezpieczeństwa” rozumiane są tutaj zarówno instytucje pozwalające na ograniczoną krytykę rządu i debatę polityczną, jak i działania administracji państwowej ukierunkowane na ugruntowywanie popularności, jaką M7 cieszy się w społeczeństwie. Wielu respondentów podkreślało, że Uganda ma ich zdaniem jedne z najlepszych praw na świecie. Również proces legislacyjny odbywa się w atmosferze gorącej debaty politycznej, zaś przed parlamentem występują reprezentanci różnych grup interesów. Jednakże jednym z głównych problemów współczesnej Ugandy jest implementacja zasad zapisanych w aktach prawnych i skuteczność w egzekwowaniu prawa ${ }^{22}$. Kwestie przyczyn nieskuteczności administracji państwowej zostały podniesione w dalszej części tekstu, tutaj należy jednak zwrócić uwagę na symboliczne znaczenie sporu politycznego dla utrzymania się NRM u władzy ${ }^{23}$. Podnoszenie przez NRM w parlamencie określonych kwestii wymagających regulacji prawnych jest strategią obliczoną na kreowanie podziałów wśród opozycji, przy jednoczesnym zachowaniu pozorów prowadzenia otwartej debaty politycznej. Innymi słowy - zgłaszanie określonych inicjatyw ustawodawczych i związana z nimi debata powinny być widziane w kontekście „wentylu bezpieczeństwa” wbudowanego w ugandyjski reżim polityczny. Kolejnym przykładem tej instytucji jest koncesjonowanie krytyków rządu. Wśród wielu osób, z którymi przeprowadzane były wywiady, istniało głębokie przekonanie, że wielu publicystów czy reprezentantów organizacji pozarządowych (pragnący pozostać anonimowym szef jednej z najbardziej aktywnych ugandyjskich NGOs stwierdził, że w każdej organizacji pozarząadowej, włączenie z tą, którą sam prowadzi, pracuje ktoś, kto działa w interesie rządu i jest przez rząd opłacany), którzy otwarcie krytykują rząd, ma oficjalne przyzwolenie władz na prowadzenie tej działalności. Innymi

${ }^{21}$ Pojęcie „wentyli bezpieczeństwa” w kontekście ugandyjskiego reżimu politycznego zostało użyte i wyjaśnione podczas wywiadu przeprowadzonego z szefową instytutu nauk politycznych Uniwersytetu Makerere dr Suzie Nansozi Muwanga.

22 Wywiad z Drake Kyalimpa, Don Bwesigye, Robert Byaruhanga, pracownicy akademiccy, Victoria University, Kampala 23.06.2014.

23 Por. T. Goodfellow, Legal Manoeuvres and Violence: Law Making, Protest and Semi-Authoritarianism in Uganda, „Development \& Change” 2014, vol. 45, issue 4, s. 753-776. 
słowy, rząd dopuszcza możliwość krytyki prowadzonych przez siebie polityk, jednakże na warunkach, które sam określa.

Przykładem „wentylu bezpieczeństwa”, który został wprowadzony celem skupienia uwagi Ugandyjczyków na innych problemach niż kwestie świadczeń społecznych czy źle działającej służy zdrowia, była debata na temat ustaw penalizujących homoseksualizm. Pomimo heterogeniczności ugandyjskiego społeczeństwa zdecydowana większość obywateli tego państw popierała rządowe projekty, a nawet opowiadała się za karaniem homoseksualizmu śmiercią ${ }^{24}$. Dzięki kontrowersjom, które nowe prawo wzbudziło na arenie międzynarodowej, M7 mógł pozycjonować się jako „obrońca tradycyjnych afrykańskich wartości”, polityk twardy, który nie pozwala państwom rozwiniętym dyktować, w jaki sposób ma wyglądać proces legislacyjny w Ugandzie. Co więcej, Uganda nie przejęła się zupełnie zamrożeniem części pomocy, którą uzyskiwała z państw europejskich, a prezydent wzywał donatorów, żeby opuścili jego kraj, jeśli chcą narzucać mu „obce wzorce kulturowe”.

Po piąte, prezydent Museveni dokłada wszelkich starań, aby ugruntowywać swój pozytywny wizerunek w społeczeństwie ugandyjskim. Funkcjonowanie sieci patronażu jest zatem wspierane przez perfomatywny wymiar sprawowania przez M7 urzędu głowy państwa. Na dużym poziomie ogólności można powiedzieć, że Museveni jest prezentowany jako ojciec narodu, który nie ma pełnej wiedzy na temat szczegółowych problemów, z którymi borykają się lokalne społeczności, ale kiedy są mu one przedstawiane, pochyla się nad nimi i próbuje je rozwiązać. Podczas podróży po kraju prezydent nie tylko stara się mówić w lokalnych językach, ale również publicznie ruga swoich doradców i ministrów za zaniedbania, a nawet przekazuje lokalnym społecznością gotówkę na realizację określonych zadań.

\section{KONKLUZJE. KONSEKWENCJE OPARCIA REŻIMU POLITYCZNEGO UGANDY NA INKLUZYJNEJ SIECI PATRONAŻU}

Podstawową konsekwencją istnienia sieci patronażu w Ugandzie jest stabilizacja polityczna, jaką daje ona temu państwu. Prezydent Museveni jest niewątpliwie osobą cierpliwą i nie podejmuje gwałtownych ruchów. Z drugiej strony funkcjonowanie patronażu wiąże się ze wspomnianą powyżej nieefektywnością

${ }^{24}$ Wywiad z dr. Anthony Okuku Juma, Makerere University, Kampala, 25.06.2014. 
administracji państwowej oraz przerostem biurokracji, co jest podkreślane nawet przez członków ugandyjskiego rządu ${ }^{25}$. Urzędnicy służby cywilnej najbardziej boją się oskarżeń o korupcję ${ }^{26}$, które mogą skutkować utratą przez nich pracy. Tym samym najbardziej racjonalną z ich punktu widzenia strategią jest przeciąganie relacji z petentem, tak by nie narazić się na podejrzenie, że „szybkie” załatwienie przez nich określonej sprawy mogło być spowodowane uzyskaniem korzyści majątkowej.

Nieefektywność ugandyjskiej administracji państwowej manifestuje się obecnie w niskiej ściągalności podatków. Wpływy podatkowe do budżetu państwa stanowią w Ugandzie zaledwie około $12 \%$ PKB - co jest wynikiem niezwykle niskim, nawet biorąc pod uwagę region Afryki Wschodniej. Jednakże nawet przy niskiej ściągalności podatków środki, które rząd ma do swojej dyspozycji stale rosną i są wystarczające dla kupowania poparcia i wprowadzania ograniczonych świadczeń społecznych ${ }^{27}$, szczególnie na terenach, które wcześniej nie otrzymywały nic od władz. Symptomatyczny w tym zakresie jest kontrast pomiędzy opiniami Ugandyjczyków mieszkających na terenach wiejskich oraz w Kampali. Autor nie przeprowadzał badań socjologicznych w tym zakresie, a poniższa opinia oparta jest na rozmowach z przypadkowo spotkanymi ludźmi, niemniej mieszkańcy stolicy niemalże zawsze narzekali na pogarszającą się jakość edukacji publicznej i opieki zdrowotnej, podczas gdy osoby zamieszkujące na wsiach podkreślały widoczne postępy w tych obszarach. Wydaje się, że niezwykle ważne przy interpretacji wyżej wymienionych opinii jest branie pod uwagę efektu niskiej bazy i różnic oczekiwań mieszkańców miast i wsi. Przez efekt niskiej bazy rozumiane jest tutaj dostarczenie jakiegokolwiek świadczenia (ujęcia wody pitnej, zbudowania szkoły etc.) w miejscu, gdzie go wcześniej brakowało. Stolica jest również bastionem opozycji, zaś poparcie dla Museveniego koncentruje się właśnie na terenach wiejskich.

Zasadne jest również postawienie pytania o moralny wymiar funkcjonowania połączeń klientelistycznych w Ugandzie i możliwość ich ocen. Sieć patronażu jest wypadkową działań mających ma celu utrzymanie się NRM u władzy przy jednoczesnym dążeniu do zachowania pokoju i stabilizacji w państwie. Niezwykle łatwo jest krytykować korupcję i nieefektywność administracji pań-

25 Wywiad z Moses W. Watasa, Commissioner of Information, Office of the Prime Minister, Directorate of Information and National Guidance, Ministry of Information, Kampala, 3.07.2014.

${ }^{26}$ Obserwacja własna autora podczas wizyt w ugandyjskich urzędach państwowych.

27 Wywiad z Andrew M. Mwenda, Strategy and Editorial Director, „The Independent”, siedziba „The Independent”, Kampala, 27.06.2014. 
stwowej w egzekwowaniu prawa, jednakże biorąc pod uwagę heterogeniczność ugandyjskiego społeczeństwa, zaszłości historyczne i niestabilność otoczenia międzynarodowego Ugandy ocena wyboru strategii politycznej NRM nie jest jednoznaczna.

Ugandyjskie ugrupowania opozycyjne podjęły w 2015 roku próbę zjednoczenia się pod szyldem Sojuszu Demokratycznego (ang. Democratic Aliance). Jednakże w obecnej sytuacji najbardziej efektywna opozycja wobec prezydenta Museveniego może powstać w łonie jego własnego ugrupowania ${ }^{28}$. Precedensem jest złożona w czerwcu 2015 roku deklaracja byłego premiera Amama Mbabaziego, że będzie się ubiegał o partyjną nominację w wyborach prezydenckich. Jednakże zdecydowana większość członków NRM jest złączona swoimi posadami z osobą prezydenta i jest mało prawdopodobne, by nominację uzyskał ktokolwiek inny niż M7.

Podsumowując, należy stwierdzić, że patroanż i klientelizm są podstawowymi cechami ugandyjskiego reżimu politycznego. Instytucje te są efektem aspiracji NRM do ustabilizowania sytuacji w państwie przy jednoczesnym dążeniu do utrzymaniu przy władzy. Sukces prezydenta Museveniego nie leży w wykluczaniu opozycji z dostępu do stanowisk państwowych, ale wynika z głęboko inkluzyjnej natury ugandyjskiego patronażu i przenikania do wielu dziedzin życia. Inkluzywność NRM jest determinowana rolą, jaką odegrał ten „bezpartyjny ruch” w latach 80. i 90. ubiegłego wieku. Nie bez znaczenia jest również świadomość społeczeństwa, że M7 mógłby używać sił bezpieczeństwa dla pozostania u władzy, jednakże świadomie wybrał inną strategię, która przekłada się na nieefektywność administracji państwowej i przydzielanie stanowisk państwowych na podstawie lojalności, a nie kompetencji. Wpływy do kasy państwowej są zaś na tyle wysokie, że umożliwiają funkcjonowanie patronażu, a jednocześnie nie istnieją żadne zachęty, aby zwiększać efektywność działań administracji państwowej.

${ }^{28}$ Podczas wywiadów z działaczami partii opozycyjnych symptomatyczne było, że w zasadzie nie wierzyli w możliwość odsunięcia M7 od władzy. 